anterior position. The more experienced practitioner may wish to extend the range of his intervention, but this should be limited to institutional conditions. There are many general practitioners in this country, including several of our former house-surgeons, who are using the instrument successfully. Further extension of this trend would help to reduce the dangers of forceps in unpractised hands and lead to improved figures for infant survival in the home, as we believe it has in the hospital.

\section{Summary}

The Malmström vacuum extractor has been employed for 400 deliveries at the Obstetric Unit, Ronkswood Hospital, Worcester, during 1948-63. In this time the incidence of vacuum extraction has increased progressively, while that of forceps delivery has fallen.

Foetal mortality has fallen progressively, and recently there has been a fall in the incidence of caesarean section. It is suggested that both of these are due in part to the use of the vacuum extractor.

Indications are described for the use of the instrument in both the first and the second stage of labour, and the results are detailed.
The method has proved effective in cases of malrotation of the foetal head and of foetal distress, and results for both mother and foetus have been satisfactory.

I am grateful to my colleague Mr. A. T. Marshall for permission to quote many of his cases included in the above series.

\section{REFERENCES}

Alment, E. A. J. (1960). Proc. roy. Soc. Med., 53, 759.

Chertkoff (1961). Proceedings of Third International Congress of Obstetrics and Gynaecology, Vienna, 1, 380.

de Azevedo, G. (1959). Portugal méd., 43, 75.

Dragotescu, C. C., and Roman, I. (1962). Vidextractia Obstetricala, Bucharest.

Evelbauer, K. (1958). Fortschr. Med., 76, 553.

(1961). Proceedings of Third International Congress of Obstetrics and Gynaecology, Vienna, 1, 82

Fothergill, R. J., and Chalmers, J. A. (1961). Practitioner, 186, 559.

Huntingford, P. J. (1961). Lancet, 2, 1054.

Malmström, T. (1961). Proceedings of Third International Congress of Obstetrics and Gynaecology, Vienna, 1, 47.

Rüther, E., and Sokol, K. (1961). Geburtsh. u. Frauenheilk., 21, 245.

Snoeck, J. (1960). Proc. roy. Soc. Med., 53, 749.

Wong, H. B. (1961). F. Singapore paediat. Soc., 3, 56.

Yonge, J. (1706-7). Phil. Trans. B, 25-26, 2387.

\title{
Serum Transaminase Activity in Status Asthmaticus
}

\author{
A. H. EL-SHABOURY,* M.B., D.C.H. ; A. J. THOMAS,* M.D., F.R.C.P. \\ D. A. WILLIAMS,* M.D., M.SC., F.R.C.P.
}

Brit. med. F., 1964, 1, 1220-1223

It has been established by Karmen (1955) that serum glutamic oxaloacetic transaminase (S.G.O.T.) activity was increased after cardiac infarction. The S.G.O.T. is of especial value when the electrocardiograph shows bundle-branch block, left ventricular strain, or previous myocardial infarction, or when digitalis obscures the changes (Dewar et al., 1958). In experimental tissue injury a rough correlation has been found between the amount of tissue injury and the peak level of S.G.O.T. (Rudolph et al., 1957), and cases of cardiac infarction with values over 200 or 250 units $/ \mathrm{ml}$. have been shown to carry a poor prognosis (Chinsky et al., 1956 ; Bruce et al., 1958). In small infarctions serial estimations may show a diagnostic curve even though the peak level does not exceed 40 units $/ \mathrm{ml}$., the upper limit of normal (Baron et al., 1958 ; Dewar et al., 1958).

It is also widely accepted that raised levels of S.G.O.T. and serum glutamic pyruvic transaminase (S.G.P.T.) occur in acute liver damage (Wroblewski and La Due, 1955, 1956a, 1956b ; Chinsky et al., 1957 ; Madsen et al., 1958). Increases may occur in patients receiving morphine, salicylates, chlorpromazine, and ethyl alcohol ; in skeletal disorders and acute pancreatitis (Wroblewski, 1959); and in atopic eczema and other skin diseases (Tickner et al., 1961). It appears unlikely that steroids have any influence on S.G.O.T. activity (Vickers, 1961).

Elevated S.G.O.T. activity was found in cardiac failure without evidence of cardiac infarction (Fragge et al., 1960). The highest levels (555 units $/ \mathrm{ml}$.) were found in patients with chronic lung disease and right heart failure. The rapidity of onset of failure in influencing the enzyme levels was emphasized.

- St. David's Hospital, Cardiff.
In 224 patients with acute cardiac failure West et al. (1961) also found elevation of S.G.O.T. and S.G.P.T. in the absence of cardiac infarction. They refer to elevation of glycolytic enzymes (lactic dehydrogenase, aldolase, and phosphohexose isomerase), possibly due to anoxia, in more than half of the patients with severe acute episodes of bronchial asthma.

Colldahl $(1960,1961)$ studied the serum enzymes in patients with "asthma and emphysema" and found definitely raised levels in about $25 \%$ of 125 asthmatic patients with varying degrees of dyspnoea. The S.G.P.T. especially was increased, the aldolase and ornithine carbamyl transferase (O.C.T.) were also sometimes elevated. Raised S.G.O.T. activity occurred in two cases with severe asthma in the absence of cardiac infarction as proved at necropsy.

Our interest arose when a patient aged 60 (Case 1 ; see Table), admitted in status asthmaticus, complained of "tightness" of his chest 36 hours after admission, while still severely distressed from his asthma. Serum enzyme estimations carried out on three successive days were S.G.O.T. 202, 147, and 116 units $/ \mathrm{ml}$. and S.G.P.T. 43, 47, and 52 units/ml. respectively. The electrocardiogram remained normal throughout his six weeks' stay in hospital and has remained so since. The high S.G.O.T. levels made us initially consider this case as one of possible cardiac infarction complicating status asthmaticus. Our subsequent experience makes this diagnosis unlikely. Recently a woman aged 30 was admitted in status asthmaticus to another hospital under the care of one of us (D.A.W.) and died within three days. The S.G.O.T. was 53 units $/ \mathrm{ml}$. on the second day. At necropsy the coronary arteries and myocardium were healthy, while the liver showed chronic venous congestion. 
So far as we are aware, no report of the serum transaminase levels in a series of 60 cases of uncomplicated status athmaticus has previously been reported.

\section{Material and Methods}

Our material consists of 60 patients admitted to this hospital with uncomplicated status asthmaticus (42 females aged 14-77, mean 47.6 years, and 18 males aged $27-75$, mean 50.2 years). The duration of asthma and the period of severe exacerbation before admission were noted in each case. All these patients were known asthmatics, having attended the asthma clinic at this hospital. With the exception of four, all have been subsequently followed-up and the diagnosis of uncomplicated asthma has been confirmed.

A patient was considered to be in status asthmaticus when he or she had persistent distressing dyspnoea due to asthma, lasting at least 24 hours and not responding to the usual doses of ephedrine, isoprenaline, adrenaline, or intravenous aminophylline. No patient with a pulse rate below 110 on admission was included in this series, the pulse rate being regarded as an indication of the severity of asthma (Williams, 1963).

All patients had serial estimations of S.G.O.T., S.G.P.T., serum bilirubin, alkaline phosphatase, Kunkel, thymol turbidity, and flocculation on admission. The S.G.O.T. and S.G.P.T. were repeated on the two subsequent days. A bromsulphthalein excretion test was carried out on 26 of the patients on admission. All patients had an $x$-ray examination of the chest to exclude pneumonia or tuberculosis. Half-hourly pulse rates were taken until the patients showed definite improvement. Each patient had at least two electrocardiograms while in hospital. Some 2 to 28 weeks later, when the asthma was reasonably well controlled, the patients were recalled for further S.G.O.T. and S.G.P.T. estimations on three consecutive days. None of them had been given, or were given, any of the drugs known to cause raised serum transaminases.

Six patients required neither corticotrophin nor steroids during the acute attack, responding to further injections of subcutaneous adrenaline and intravenous aminophylline. Two were treated with prednisone only. The remaining 52 received intramuscular corticotrophin; in 30 a more rapid response to therapy was thought desirable and intravenous corticotrophin infusions were also given. Morphine was not used.

Special care was taken to exclude any patient with hepatomegaly and cardiac failure or with electrocardiographic changes in any way suggestive of myocardial ischaemia. No patient with any other condition which might have accounted for a raised transaminase activity was included.

Transaminase activity was determined by the colorimetric method described in Sigma Technical Bulletin No. 505 after Reitman and Frankel (1957). The normal value for the S.G.O.T. is $8-40$ units $/ \mathrm{ml}$., and for S.G.P.T. values of $36-45$ units $/ \mathrm{ml}$. constitute a borderline rise. A senior technician carried out the estimations, the methods and reagents being checked by a biochemist.

The S.G.O.T. and S.G.P.T. were estimated in 45 healthy persons. This group consisted of 14 males, aged 17-62, mean 39.3 years and 31 females, aged $18-61$, mean 33.7 years. The S.G.O.T. activity ranged from 9 to 36 units $/ \mathrm{ml}$., mean 17.9 (S.D. \pm 6.5 ), and for the S.G.P.T., 4-28 units/ml., mean 11.6 (S.D. \pm 5.6).

\section{Results}

Details of the 10 patients who showed a significant rise in S.G.O.T. activity (above 50 units $/ \mathrm{ml}$.) during status asthmaticus are shown in the Table.

During status asthmaticus (first three days in hospital), 24 patients $(40 \%)$ showed a rise in S.G.O.T. activity on at least one estimation. A significant rise was found in $10(16.7 \%)$ (Cases 1-10), and a borderline rise (41-50 units $/ \mathrm{ml}$.) in 14 $(23.3 \%)$. S.G.P.T. activity was elevated in $12(20 \%)$, significantly (above 45 units $/ \mathrm{ml}$.) in 8, and a borderline rise (36-45 units $/ \mathrm{ml}$.) in 4 cases. The S.G.O.T. was in excess of S.G.P.T. activity in 21 out of the 24 cases-that is, in $87.5 \%$. Thirtysix patients $(60 \%)$ had no rise in S.G.O.T. activity.

When not in status asthmaticus, of the 56 patients who had their transaminases re-estimated, $11(19.6 \%)$ showed a rise in S.G.O.T. activity on at least one estimation. A significant rise was found in $3(5 \%)$ and $8(14.6 \%)$ showed a borderline rise. S.G.P.T. activity was increased in 7 (12.5\%), two having a significant rise, and five having a borderline rise. Five patients had a higher transaminase activity while their asthma was controlled than during status asthmaticus.

The thymol turbidity and albumin/globulin ratios were normal in all cases. Alkaline phosphatase was 14.3 units $/ \mathrm{ml}$. in one patient and normal in all others. Serum bilirubin was $1.2,1.6$, and $1.7 \mathrm{mg} . / 100 \mathrm{ml}$. in three cases. Thymol flocculation tests were abnormal in 20 cases. Of these, 10 had a rise in S.G.O.T. activity. Of the 26 patients who had a bromsulphthalein test, 15 had abnormal retention of dye, ranging from $6.5 \%$ to $36 \%$ after 45 minutes. Of these 15,4 had increased transaminase activity, while 11 showed no increase. Of the remaining 11 patients with a normal bromsulphthalein test, 6 had elevation of transaminase activity, in 2 significantly.

Forty-four patients had electrocardiograms taken during the first two days in hospital. Of these 44,25 showed the changes seen during attacks of asthma, which are attributed by SodiPallares and Calder (1956) to the shift of position of the heart incident to temporary dilatation of the right heart chambers. The 25 records showed negative RS-T displacement in leads II, III, and AVF, and tall and peaked $P$ waves ranging from 3 to $4.5 \mathrm{~mm}$. in height, the width being normal. Of these 25 cases eight had elevated transaminase levels during status asthmaticus.

Of the six patients who had neither corticotrophin nor steroids, four (Cases 4, 5, 7, and 10) had significantly elevated

Details of those Patients Showing a Significant Rise in S.G.O.T. Activity (Above 50 units/ml.) During Status Asthmaticus

\begin{tabular}{|c|c|c|c|c|c|c|c|c|c|c|c|c|c|c|c|c|c|c|c|c|}
\hline \multirow{2}{*}{$\begin{array}{l}\text { Case } \\
\text { No. }\end{array}$} & \multirow{2}{*}{$\mid \begin{array}{c}\text { Age } \\
\text { in } \\
\text { Years }\end{array}$} & \multirow{2}{*}{ Sex } & \multirow{2}{*}{$\begin{array}{c}\text { Duration } \\
\text { of } \\
\text { Asthma } \\
\text { (Years) }\end{array}$} & \multirow{2}{*}{$\begin{array}{c}\text { Acute } \\
\text { Exacer- } \\
\text { bation } \\
\text { (Days) }\end{array}$} & \multirow{2}{*}{\multicolumn{3}{|c|}{$\begin{array}{l}\text { Average Pulse/min. } \\
\text { During First Three } \\
\text { Days in Hospital }\end{array}$}} & \multicolumn{13}{|c|}{ Serum Enzyme Levels in Units/ml. } \\
\hline & & & & & & & & \multicolumn{3}{|c|}{ S.G.O.T. } & \multicolumn{3}{|c|}{ S.G.P.T. } & $\begin{array}{c}\text { No. } \\
\text { Weeks } \\
\text { Elapsed }\end{array}$ & \multicolumn{3}{|c|}{ S.G.O.T. } & \multicolumn{3}{|c|}{ S.G.P.T. } \\
\hline $\begin{array}{r}1 \\
2 \\
3 \\
4 \\
5 \\
6 \\
7 \\
8 \\
9 \\
10\end{array}$ & $\begin{array}{l}60 \\
77 \\
40 \\
23 \\
47 \\
54 \\
64 \\
38 \\
62 \\
38\end{array}$ & $\begin{array}{c}\mathbf{M} \\
\mathbf{F} \\
\mathbf{F} \\
\mathbf{F} \\
\mathbf{F} \\
\mathbf{F} \\
\mathbf{F} \\
\mathbf{F} \\
\mathbf{M}\end{array}$ & $\begin{array}{r}4 \\
8 \\
35 \\
18 \\
1 \\
24 \\
5 \\
23 \\
4 \\
1\end{array}$ & $\begin{array}{r}3 \\
7 \\
7 \\
14 \\
3 \\
21 \\
14 \\
7 \\
10 \\
8\end{array}$ & $\begin{array}{l}120 \\
110 \\
140 \\
110 \\
120 \\
120 \\
110 \\
120 \\
140 \\
120\end{array}$ & $\begin{array}{r}110 \\
100 \\
116 \\
100 \\
110 \\
110 \\
100 \\
96 \\
110 \\
110\end{array}$ & $\begin{array}{r}100 \\
100 \\
100 \\
90 \\
100 \\
100 \\
80 \\
88 \\
90 \\
100\end{array}$ & $\begin{array}{r}202 \\
117 \\
68 \\
86 \\
86 \\
77 \\
71 \\
67 \\
46 \\
26\end{array}$ & $\begin{array}{r}147 \\
150 \\
108 \\
* \\
31 \\
31 \\
* \\
19 \\
62 \\
60\end{array}$ & $\begin{array}{r}116 \\
31 \\
61 \\
68 \\
41 \\
41 \\
27 \\
20 \\
55 \\
40\end{array}$ & \begin{tabular}{|r|}
43 \\
162 \\
43 \\
47 \\
68 \\
49 \\
88 \\
31 \\
35 \\
\end{tabular} & $\begin{array}{r}47 \\
198 \\
27 \\
22 \\
16 \\
* \\
12 \\
39 \\
26\end{array}$ & $\begin{array}{r}52 \\
22 \\
31 \\
* \\
31 \\
23 \\
20 \\
5 \\
52 \\
27\end{array}$ & $\begin{array}{r}20 \\
5 \\
12 \\
21 \\
20 \\
2 \\
8 \\
8 \\
8 \\
2\end{array}$ & $\begin{array}{l}36 \\
27 \\
26 \\
17 \\
17 \\
25 \\
45 \\
20 \\
22 \\
30\end{array}$ & $\begin{array}{c}40 \\
30 \\
27 \\
6 \\
14 \\
13 \\
31 \\
22 \\
31 \\
22\end{array}$ & $\begin{array}{l}45 \\
45 \\
36 \\
14 \\
16 \\
16 \\
26 \\
16 \\
31 \\
35\end{array}$ & $\begin{array}{l}26 \\
30 \\
19 \\
15 \\
19 \\
28 \\
40 \\
13 \\
26 \\
27\end{array}$ & $\begin{array}{l}31 \\
35 \\
25 \\
15 \\
18 \\
22 \\
22 \\
18 \\
35 \\
30\end{array}$ & $\begin{array}{l}26 \\
42 \\
22 \\
12 \\
16 \\
21 \\
22 \\
18 \\
22 \\
35\end{array}$ \\
\hline
\end{tabular}

* Transaminase results mislaid. 
transaminase activity and two had no rise. Analysis of the 60 patients' transaminase results shows that neither the age of the patient, nor duration of acute exacerbation of asthma before admission, nor the degree of tachycardia affected the transaminase results.

Of the 36 patients who had no rise in transaminase activity, 10 have since been readmitted in status asthmaticus. Of these 10 , five had a rise in transaminase activity, two significantly and three borderline. Of the 24 patients who had a rise in transaminase activity, seven were readmitted in status asthmaticus. Of these seven, two had raised levels.

Three patients died, one man and two women. The man, aged 32 , had had asthma for five years and the transaminase results showed a borderline rise in S.G.O.T. activity during status asthmaticus. The S.G.P.T. was significantly elevatedthat is, 51,60 , and 46 units $/ \mathrm{ml}$. on three consecutive days nine weeks later when his asthma was well controlled. Six months later he was readmitted in status asthmaticus and died after eight hours. On this occasion the transaminases were normal and the bromsulphthalein was $15 \%$ after 45 minutes. One of the women, age 68, had had asthma for three years and died in status asthmaticus after three days in hospital. The bromsulphthalein test was $13 \%$ on admission and the transaminases were normal during the three days. The other woman, aged 41, who had had asthma for five years was admitted in status asthmaticus and died eight hours after admission. The transaminases were normal and the bromsulphthalein was $16 \%$ after 45 minutes. Necropsy findings were identical in the three cases and showed the typical widespread plugging of bronchioles. Right heart chambers were dilated but not hypertrophied; coronary arteries and myocardium were normal. The liver showed acute congestion but no necrosis.

\section{Discussion}

Although systemic steroids markedly increase the G.P.T. content of rat-liver cells (Gavasto et al., 1957 ; Rosen et al., 1958), we have not been able to trace any report of corticotrophin or steroids causing elevated serum transaminases. Vickers (1961) found no elevation of S.G.O.T. activity following systemic steroid therapy in 11 dermatological cases. In our patients who were given steroids or corticotrophin the proportion with elevated transaminases was lower than in the group of six who did not have this treatment. Moreover, six healthy persons and five asthmatic patients, while their asthma was well controlled, were given infusions of 20-40 units of corticotrophin and showed no rise of either transaminase when estimated six to eight hourly for 48 hours and again at 72 hours (El-Shaboury, unpublished). We therefore have no evidence suggesting that corticotrophin or steroids might have increased the serum transaminase levels.

So far as possible we have excluded coronary artery disease in our cases, although we appreciate that this can be present in the absence of electrocardiographic changes. Any cases which had signs of cardiac failure were also excluded, but slight degrees of failure can be difficult to diagnose in an asthmatic sitting up acutely distressed. We consider that very severe asthma may cause temporary acute cardiac failure, although little work on the changes in pulmonary circulation in acute attacks has been done (Helander et al., 1962). In the three cases which went to necropsy, the bromsulphthalein test was abnormal, the right heart dilated, and the liver acutely congested. Our findings of abnormal flocculation tests in a third of the cases, bromsulphthalein retention in 15 out of 26 cases, and electrocardiographic changes consistent with right heart strain are of interest. West et al. (1961) found bromsulphthalein retention in $97 \%$ of cases of acute cardiac failure and a direct correlation between the degree of dye retention and height of venous pressure. However, they did not discuss the relation between bromsulphthalein retention and transaminase levels. We have not found any correlation between elevated transaminase activity and bromsulphthalein retention in status asthmaticus.

Prolonged anoxia causing damage to liver cells may also explain elevated transaminase activity. The centrilobular hepatic cells are particularly vulnerable (Sherlock, 1951). Colldahl (1943) found liver damage in rats subjected to severe experimental asthma or to low oxygen and high carbon-dioxide tension. Asvall (1960) found, in rabbits subjected to hypoxia, raised transaminase activity after 30 minutes, reaching a peak level in three hours, and returning to normal in 20 hours. It has long been appreciated that hypoxaemia occurs during asthmatic attacks (Schiller and Lowell, 1954 ; Lukas, 1951), and hypercapnia was found in 5 out of 15 cases by Williams and Zohman (1960). In seven patients with status asthmaticus studied by Feldman (1962) arterial $\mathrm{PCO}_{2}$ ranged from 33 to $83 \mathrm{~mm}$. $\mathrm{Hg}$, and $\mathrm{O}_{2}$ saturation from 48 to $96 \%$. Colldahl (1960) attributed his elevated transaminase levels to liver damage caused by "insufficient gas exchange," and in one patient with raised enzyme levels who died in status asthmaticus centrilobular necrosis of the liver was found. In our cases we have not found a definite correlation between abnormal liverfunction tests and elevation of transaminase activity. We have no explanation for elevated transaminase activity in 12 of the cases while their asthma was controlled some 2 to 28 weeks later. Tissue damage and release of intracellular enzymes occur during the allergic reactions (Ungar and Hyashi, 1958 ; Becker, 1958 ; Godlowski et al., 1962). It is just possible that such release of intracellular enzymes contributes to elevated transaminase levels in status asthmaticus.

Increased transaminase levels occur far more often in status asthmaticus than after recovery, and, to this extent only, they indicate the seriousness of the asthmatic state as suggested by Colldahl. However, in status asthmaticus we have not found that elevated enzyme levels confirmed our grading of clinical severity. Moreover, some of our patients who showed a rise in transaminase levels did not necessarily have a rise on subsequent admissions in status asthmaticus. The severity of the illness appeared clinically to be the same as during their first admission. Similarly, a proportion of those who initially had no rise showed a rise on further admission. In two of the patients who died the levels were normal. Clearly, more accurate and measurable assessment of the respiratory and cardiac state in status asthmaticus is required.

We are in agreement with Colldahl that in severe asthma elevated transaminases can occur and that the finding of an elevated S.G.O.T. does not necessarily indicate that cardiac infarction has also taken place.

\section{Summary}

The levels of S.G.O.T. and S.G.P.T. in 60 patients with uncomplicated status asthmaticus and in 56 after recovery are presented.

In status asthmaticus 24 cases $(40 \%)$ had a rise in S.G.O.T., significantly in 10. The S.G.O.T. was in excess of S.G.P.T. in $87.5 \%$ of cases showing a rise in transaminase activity. In 20 out of 60 patients minor alterations occurred in flocculation tests, and in 16 out of 26 bromsulphthalein excretion was abnormal.

After recovery, $11(19.6 \%)$ had a rise in S.G.O.T., in $3(5 \%)$ significantly. Seven $(12.5 \%)$ had a rise in S.G.P.T. activity, in 2 significantly.

The cause of the raised transaminases in status asthmaticus is not certain, and possible mechanisms are discussed. Although liver damage may be part of the explanation, the liver-function tests failed to show a definite correlation with raised serum transaminase activity. Further investigation is required.

We did not find the transaminase levels of value in assessing the severity or prognosis in status asthmaticus. 
A high S.G.O.T. level may occur in status asthmaticus in the absence of myocardial infarction.

We are indebted to members of the United Cardiff Hospitals for criticism; to Dr. D. M. D. Evans, consultant pathologist ; and to members of his department of chemical pathology at St. David's Hospital, particularly to Mr. J. Clarke, F.I.M.L.T., and K. W. Davies, B.Sc., Ph.D., for transaminase estimations.

\section{REFERENCES}

Asvall, J. E. (1960). Scand. F. clin. Invest., 12, 247.

Baron, D. N., Alezander, C. P., Bell, J. L., and Oakley, C. M. (1958). Quart. F.' Med., 27, 533.

Becker, E. L. (1958). F. Allergy, 29, 191.

Bruce, R., Todd, J. K., and LeDune, L. (1958). Brit. med. 7., 2, 1125.

Chinsky, M., Shmagranoff, G. L., and Sherry, S. (1956). f. Lab. clin. Med., 47, 108.

Wolf, R. J., and Sherry, S. (1957). Amer. F. med. Sci., 233, 400.

Colldahl, H. (1943). Acta physiol. scand., Suppl. No. 8.

- (1960). Acta med. scand., 166, 399.

(1960). Acta med. scand., 166, 399.

York, October 1961. Amsterdam, Excerpta Medica Foundation, International Congress Series, 42, 25. International Congress Series, 42,
1121. A., Rowell, N. R., and Smith, A. J. (1958). Brit. med. F., 2,

Feldman, R. (1962). Ann. intern. Med., 57, 29.
Fragge, R. G., Kopel, F. B., and Iglauer, A. (1960). Ibid., 52, 1042. Gavasto, F., Pileri, A., and Brusca, A. (1957). Biochim. biophys. Acto (Amst.), 24, 250.

Godlowski, Z. Z., Calandra, J. D., and Baron, H. J. (1962). Ann. Allergy, $20,437$.

Helander, E., Lindell, S. E., Söderholm, B., and Westling, H. (1962). Acta allerg. (Kbh.), 17, 112.

Karmen, A. (1955). F. clin. Invest., 34, 131.

Lukas, D. S. (1951). ₹. Allergy, 22, 411 .

Reitman, S., and Frankel, S. (1957). Amer. F. clin. Path., 28, 56.

Rosen, F., Roberts, N. R., Budnick, L. E., and Nichol, C. A. (1958) Science, 127, 287.

Rudolph, L. A., Schaefer, J. A., Dutton, R. E., and Lyons, R. H. (1957). 7. Lab. clin. Med., 49, 31 .

Schiller, I. W., and Lowell, F. C. (1954). F. Allergy, 25, 364.

Sherlock, S. (1951). Brit. Heart f., 13, 273.

Sodi-Pallares, D., and Calder, R. M. (1956). New Basis of Electrocardiography, p. 244. Mosby, St. Louis, Mo.

Tickner, A., Mier, P. D., and McCabe, M. P. (1961). Brit. 7. Derm., 73, 180 .

Ungar, C., and Hyashi, H. (1958). Ann. Allergy, 16, 542.

Vickers, C. F. H. (1961). Brit. F. Derm.; 73, 185.

West, M., Gelb, D., Pilz, C. G., and Zimmerman, H. J. (1961). Amer. 7. med. Sci., 241, 350 .

Williams, D. A. (1963). Chest Dis. Index, 18, 95.

Williams, M. H., and Zohman, L. R. (1960). Amer. Rev. resp. Dis., 81, 173 .

Wroblewski, F. (1959). Amer. F. Med., 27, 911.

- and La Due, J. S. (1955). Ann. intern. Med., 43, 345.

- (1956a). Proc. Soc. exp. biol. (N.Y.), 91, 569. (1956b). F. Amer. med. Ass., 160, 1130.

\title{
A Survey of Antibodies to Respiratory Syncytial Virus in the Population*
}

\author{
M. H. HAMBLING, $\dagger$ M.D., DIP.BACT.
}

Brit. med. F., 1964, 1, 1223-1225

The respiratory syncytial (R.S.) virus has been shown to be an important cause of respiratory disease in young children and can account for at least one-fifth of the serious respiratory illnesses of infants (Chanock et al., 1961 ; McClelland et al., 1961 ; Adams et al., 1963). In adults the virus appears to be associated with a much less severe respiratory illness (Johnson et al., 1961, 1962). Presumably if infection with the virus is widely prevalent in children, serological studies on persons in the older age groups should reveal a high incidence of past infection. Few studies of this nature have been reported, although a small survey on the incidence of complement-fixing (C.F.) antibody, mainly in members of the younger age-groups, was described by Moss et al. (1963). During the past three years many sera have been examined for C.F. and neutralizing antibodies to the "Long" strain of R.S. virus. The following report contains the results of such tests on sera collected from persons of all age-groups and from umbilical cord blood.

\section{Materials and Methods}

Sera.-The 329 samples of serum examined were collected for various investigations from patients in hospitals during the period October 1960 to March 1962. Most of these attended the out-patient departments, but some, especially in the younger age-groups, were in-patients. None of them was considered to be suffering from acute respiratory illness when the serum was collected. They were divided by age into eight groups, with an additional group for sera from umbilical cord blood.

Virus strain.-The "Long" strain of R.S. virus was used for the preparation of C.F. antigen and infective virus suspen-

\footnotetext{
* This paper formed part of a thesis approved by the University of London for the degree of M.D.
}

† Virus Reference Laboratory, Colindale, London. sions. The original isolation of this strain from a child with lower respiratory disease was reported by Chanock et al. (1957).

\section{Serological Tests}

Neutralization.-Serial fourfold dilutions of serum, inactivated at $56^{\circ} \mathrm{C}$. for 30 minutes, were made in SM 199 containing $0.09 \%$ sodium bicarbonate. At each dilution $0.5 \mathrm{ml}$. was mixed with an equal volume of virus suspension containing an estimated $100 \mathrm{TCD}_{50} / 0.1 \mathrm{ml}$. After holding at room temperature for one hour, $0.2 \mathrm{ml}$. of serum-virus mixture was inoculated into each of four HeLa culture tubes which contained $0.8 \mathrm{ml}$. of maintenance medium (SM 199 with $5 \%$ heatinactivated rabbit serum, $0.22 \%$ sodium bicarbonate, and antibiotics). A virus titration and control cultures of virus, serum, and tissue were included in each batch of tests. Cultures were incubated at $36-37^{\circ} \mathrm{C}$. in stationary racks. Cultures were examined microscopically for characteristic cytopathic effect (C.P.E.) The extent of the cell sheet affected by C.P.E. was estimated visually and recorded as \pm (occasional scattered areas of C.P.E.), $+(25-50 \%),++(50-75 \%)$, and $+++(75-100 \%)$. Final readings were made two days after the virus controls inoculated with $100 \mathrm{TCD}_{50}$ showed +++ C.P.E. Neutralization was considered to have occurred in those cultures in which the + C.P.E. was inhibited. The virus titration indicated that the actual dose of virus used in the tests was within the range 32-320 $\mathrm{TCD}_{50} / 0.1 \mathrm{ml}$. Fifty per cent. serum neutralization end-points were calculated by the method of Reed and Muench (1938), and titres are given as the reciprocal (expressed in logarithms to the base 10) of the initial serum dilution.

Complement-fixation.-Antigen was prepared from HeLa cell cultures grown in medical prescription bottles and maintained on a medium of SM 199 containing $5 \%$ heat-inactivated 